\title{
A CALL-based Lesson Plan for Teaching Reading Comprehension to Iranian Intermediate EFL Learners
}

\author{
Hooshang Khoshsima \\ Deparment of English Language, Chabahar Maritime University, Chabahar, Iran \\ E-mail: Khoshsima2002@yahoo.com \\ Mahboobeh Khosravani (Corresponding author) \\ Deparment of English Language, Chabahar Maritime University, Chabahar, Iran \\ E-mail: Khosravani7@gmail.com
}

Doi:10.7575/aiac.alls.v.5n.2p.171

URL: http://dx.doi.org/10.7575/aiac.alls.v.5n.2p.171
Received: $02 / 03 / 2014$

Accepted: 16/04/2014

\begin{abstract}
The main purpose of this descriptive research is to provide a CALL (Computer-Assisted Language Learning)-based lesson plan for teaching reading comprehension to Iranian intermediate EFL learners. CALL is a new way of learning and teaching language. It is proved that CALL mainly has positive effects on educational contexts. Although teachers believe that CALL will have positive effect in the process of learning a language, they prefer the traditional methods. The reason is that they do not have a guide to work based on it. As a result, this study tries to design a CALL-based lesson plan to suggest not only the teachers, but also the students to examine the benefits of the method.
\end{abstract}

Keywords: Comprehension, CALL, Lesson plan

\section{Introduction}

During the process of learning a language, we deal with four skills of reading, speaking, writing, and listening. Among these four skills, reading receives the main focus for many reasons such as being able to read for educational purposes, for future jobs, for pleasure, for information. According to Chastain (1988) "reading is a process involving the activation of relevant knowledge and related language skills to accomplish an exchange of information from one person to another." (p.216). Nunan (2006) considers reading as an active skill and unlike speaking, it is not something that every individual learns to do. He believes that "an enormous amount of time, money, and effort is spent teaching reading around the world." (p.249) As soon as a child is exposed to a language he/she has to start with his/her reading skill. The crucial thing for becoming fluent readers is learning how to comprehend what they read.

Reading comprehension involves several tasks like reading, knowing the meaning of words, being aware of idioms and expressions and so on. As a result, it is so important to find a way to help the students to learn how to comprehend a text.

According to Duke and Pearson (2002) research on reading comprehension has a long and rich history. Myriad studies in the literature have examined the nature of reading comprehension as a process and about effective reading comprehension instruction. Without knowing how to comprehend a text, one cannot understand the meaning of a text. Although there are a lot of researches on reading comprehension, the students still face a lot of problems (Nunan, 2006.P.249). All the time the researchers are working on this issue to find an effective way for teaching reading comprehension.

In the process of learning, there are a lot of changes in human thoughts and the way of solving the problem of learning a language. In psychology, we can mention these changes from behaviorism to cognitivism and now to constructivism, which is the foundation of CALL (Computer Assisted Language Learning) (Cooper, 1993). Constructivism theory is based on experimenting. Constructivists believed that when we learn something, we should provide a relationship between new notions and old ones. Among different ways of teaching reading comprehension, the researcher chose the newest one, which is CALL. CALL is somehow a new issue in teaching environment as it started in 1960s and70s; as a result, it needs more work and researches (Moras, 2001).

As computers have become widespread in schools, homes, and business, a need for language learning has become urgent and the necessity of computer literacy has become very obvious, language teachers have started to use new technologies as a new pedagogical tool in foreign language teaching (Seljan, Berger\& Dovedan, 2002).

According to Moras (2001) CALL has been used since the 1960s and 1970s, but it still lacks a clear research methods. CALL development can be divided into three phases: Behaviorist, Communicative, and Integrative. At first the use of CALL in educational situations was very limited. 
We can use Computer-Assisted Language Learning in different fields of teaching like teaching vocabulary, grammars, composition, pronunciation, and reading comprehension. In this research, the researcher will work on using CALL for teaching reading comprehension. As a result, a CALL-based lesson plan will be proposed.

This study seeks to find the best CALL-lesson plan to help not only the teachers but also the students to comprehend a text better and independently. As a result, during this research the following questions will be investigated:

Q1: How to use CALL in the process of teaching reading skills?

Q2: How to produce a CALL-based lesson plan to help students to comprehend a text?

\section{Review of Related Literature}

\subsection{Nature of Reading comprehension}

Reading is perceiving a written text in order to understand its contents. This can be done silently. The understanding that results is called reading comprehension (Richards \& Schmidt, 2002).

Richards and Schmidt (2002, P.443) argued that there are three types of reading comprehension according to reader's purposes in reading and the type of reading used.

A: Literal comprehension: reading in order to understand, remember, or recall the information explicitly contained in a passage.

B: Inferential comprehension: reading in order to find information which is not explicitly the reader's experiences and intuition, and by inferring.

C: Critical or evaluative comprehension: reading in order to compare information in a passage with the reader's own knowledge and values.

D: Appreciative comprehension: reading in order to gain an emotional or other kind of valued response from a passage.

Among different ways of comprehending a text the newest one which is CALL will be investigated in this paper.

\subsection{The Definition of CALL}

Richards and Schmidt (2002, P.101) stated the definition of CALL as the use of a computer in the teaching or learning of a second or foreign language. They also cited that CALL may take the form of

A: activities which parallel learning through other media but which use the facilities of the computer.

B: activities which are extensions or adaptations of print-based or classroom based activities.

C: activities which are unique to CALL.

According to Arishi (2012), before starting reviewing literature on CALL, it is valuable to give some definitions about CALL along with emphasizing some aspects which are beneficial in the process of learning and teaching. The previous researchers have come up with slightly differing definitions of CALL which varies depending on which aspect of it is important for researchers. Egbert (2005), for example, defined CALL as "using computers to support language teaching and learning in some way" (p. 4). Her definition covers all language skills with no exception.

Beatty (2003) defines CALL as "any process in which a learner uses a computer and, as a result, improves his or her language" (p. 7). Similarly, Levy (1997), stated that CALL is "the search for and study of applications of the computer in language teaching and learning" (p.1)

\subsection{The History of CALL}

Computers have been used for language teaching ever since the 1960's. "This 40-year period can be divided into three main stages: behaviorist CALL, communicative CALL, and integrative CALL. Each stage corresponds to a certain level of technology and certain pedagogical theories"(Lee, 2000). In 1960s the term Computer Assisted Language Instruction (CALI) was common in USA, until CALL became the superior term. During the 1980s CALL became widely known and passed on, focusing the communicative approach and some new technologies, mainly multimedia and communications technology. In early 1990s, CALL was substituted with Technology Enhanced Language Learning (TELL), which appeared to have a closer description of activities which belong to CALL. In fact, TELL didn't become as widespread as CALL was.

\subsection{Researches on CALL}

As the computers became widespread everywhere, the researchers started to work on different aspects of using computers in the process of teaching and learning foreign languages. As a result, nowadays CALL is one of the most favorite field of research for researchers. In this section, the researcher will explore the different studies on CALL, different attitudes toward it, and different CALL-based lesson plans.

Many researchers have tried to prove the significant effect of CALL on learning foreign languages. (Chen, 1996; Fallon and Brown, 2003; Morrison, 2003; Dudeney and Hockly,2008; Chapelle, 2003; Lee, 2000)

Fardy, Namdar, Farhadi, Shorabi, Saboori(2011) explored the effects of CALL on the reading comprehension of expository texts. The subjects of this research were divided into two groups, control group and experimental group. For experimental group computer-assisted instructions were used. On the other hand, control group received their instruction through traditional ways. Before instruction, both groups took pre-test followed by a 12 weeks follow up 
posttest. The results proved that there were statistically considerable differences between two groups because of using CALL-based instruction on reading comprehension.

On the other hand, others provided some negative aspects of CALL. For example, Lee (2000) said that "engaging in Computer Assisted Language Learning is a continuous challenge that requires time and commitment" (p. 5)

There is a research about advantages and disadvantages of computer technology on second language acquisition, in which the researchers, Kritsonis and Lai (2006), explore four reasons about the disadvantages of using CALL. The first one as Gips, DiMattia, and Gips (2004) indicated is that using CALL will raise instructive prices and decrease the fairness of educational process. In other words, poor students won't be able to have the same instructions as others. Second, using CALL in the process of learning and teaching needs basic knowledge of computers and technology for both teachers and students. The condition will be worst when teachers themselves don't have the knowledge of technology, as a result they cannot help their students. Third, as CALL is a new phenomenon, its functions are not still developed. As a result, we cannot use CALL for all skills. Forth, computers are unable to manage unpredictable situations. This is an important weakness, as the process of learning a language is full of unexpected happenings.

Some researchers tried to explore the students' attitude toward using CALL in the process of learning. As an example, Ashiri (2012) tried to find out the students' attitude at Saudi Arabia's Industrial Colleges toward CALL. The result of this study showed that students had positive attitudes toward CALL. In general, learning with CALL was very interesting for students. Another example was conducted by Onsoy (2004), who worked on students' and teachers' attitudes toward using CALL. The findings of the study indicated that students and teachers had positive attitudes towards the use of computers in educational instruction. The findings also demonstrated that students and teachers believed that CALL training is necessary especially for teachers to learn how to teach with CALL.

Now it is clear that although CALL has some limits, mainly it has positive effects on the quality of learning foreign languages. To conclude, it can be said that both students and teachers have positive attitudes toward using CALL. The main problem is that teachers don't know how to start using CALL. Nowadays all schools have computers, but it is not enough. Although teachers know the positive effects of CALL on learning, they prefer to use traditional ways of teaching. The reason is that teachers are afraid of using a new technology in the process of teaching, because they don't have a specific frame about how to use CALL. As a result, this study tried to provide a CALL-based lesson plan for teaching reading comprehension.

\section{Methodology}

\subsection{Method and Design}

This study was descriptive in nature. Type of research question was qualitative. In this study, the researcher worked in a way to design a CALL-based lesson plan for teaching reading comprehension.

\subsection{Procedures}

The aim of this study is to design a CALL-based lesson plan, which can be used for all texts, in all settings, for all learners. At first, the researcher will try to understand different aspects and uses of CALL fully, and then she thought about different ways of learning reading comprehension. The researcher studied a lot of lesson plans and found out their weaknesses. So this study tried to reduce those weaknesses.

\subsection{Data Collection}

As mentioned before, this study is very innovative and the researcher's aim was to design a useful CALL-based lesson plan. As the research is descriptive, we do not have any quantitative data.

\section{Results and Discussion}

In this essay, it became clear that both teachers and students had positive attitudes toward using CALL in language learning and teaching. They also believe that CALL will have positive effects on students. CALL is a new way of learning a language, so teachers need a guide to use it. The current study aimed at helping teachers by providing a CALL-based lesson plan. This plan aims at helping not only teachers but also students. In this part the lesson plan will be provided.

\subsection{CALL-based Lesson Plan}

This lesson plan is about colors. At the end of this activity, students should be aware of different colors and different mixtures. This lesson is organized in a way that teachers themselves can change it for each lesson. In other words, this lesson plan is a frame work that enables the teachers to start designing their own lesson plan. 
Preparing a new situation by

doing the following activities:

Opening the teacher's weblog and the part of "teaching colors" in it.

Showing the first two slides on the computer (that show the question "What color is it?" and masses of colors with a question mark under them.)

Who can ever see rainbow? The teachers ask them to search for this web to see rainbow:

http://en.wikipedia.org/wiki/Rainbow

Who can estimate about the number of all colors? After receiving different responses from students, we ask them to go to these cites to see the large number of colors.

http://www.colorhexa.com/color-names

http://en.wikipedia.org/wiki/List of colors (compact)

Who knows combination of different colors to have extra colors?

You can see different mixture colors in these URLs.

http://michaelbach.de/ot/col mix/

http://www.enchantedlearning.com/crafts/ Colormixing.shtml
- The teacher should provide the necessary background. (By asking different questions, by helping students to see different colors in different websites, by asking about their favorites.)

- The teacher should attract his students' attention. (By pointing to real objects, showing attractive slides on computer.)

- Students should understand what they want to learn and become familiar with it.(through the teacher's weblog and beautiful slides)

- Students learnt in advance how to search on internet. (So now the teacher should help them whenever they have problem with searching those URLs.)

-The teacher should give the students enough time to see the colors carefully and talk with other students about those colors.
- Computer

(power point)

- Internet

(the teacher's weblog, different URLs)

- Role playing

(asking questions

$30 \mathrm{~min}$ 
The students are given the passages on their computers.

\section{$\{$ The teacher tells them that they can find the meaning of new words by searching on the electronic dictionary which is installed on their computers.}

We asked them to click on the names of the different colors on the text to see the exact colors.

The students were told to have the headphones.

The can hear the reading, they can stop it and listen to it again and again.
- The teacher should attract his students' attention. (by using the computer )

The students should concentrate on the present topic (colors) and think about it. (By giving a passage about colors.)

- The students should be active and

they themselves use the computer

(by using the computer, online dictionaries, and headphones)

- There is no limitation to number of listening reading, they can even listen to it more than three times. (The students have headphones, so there is no inconvenience for those who want to work on next exercises.)
The next activity is answering different questions for evaluating.

Wanting students to go to next slide and answer the questions according to text. The questions are essay type and multiple questions.(the students should type and choose the correct answer on computer, and the teacher can see all the answers on his own computer.)

Wanting students to visit the teacher's weblog and see their homework in it. They also can ask their questions via the teacher's email.
- Students should be active in the class.(pair work, surfing the net,etc)

- Evaluation of what they learnt about the passage.

- Students should also use the computer and internet at home. (giving homework \& and answering the questions via the net)
- Computer

(power point)

- Internet

-Online dictionaries

$30 \mathrm{~min}$

-Headphones

- Computer

(power point, playing

a music while the

pair work is

performing)

- Internet

(the teacher's weblog

and surfing the net as

the final evaluation

$30 \mathrm{~min}$

\section{Conclusion}

As already mentioned, this study tried to provide a CALL-based lesson plan. The given lesson plan is a general sample, so the teachers themselves can design appropriate ones for their specific lessons. As one of the difficulty of teachers is how to use CALL in the process of language learning, so the aim of this study was to make teachers familiar with the use of CALL in process of teaching.

This study has a number of implications. First of all, it might provide helpful hints for syllabus designers to provide CALL-based syllabuses. Second, teacher trainers might use the results of the study to change the attitudes of teachers toward using technology in the process of teaching. Third, this study can act as a provoker for teachers to use CALLbased lesson plan in their classes. The last one is that the lessons become more interesting for students, so they will have more interaction in the class. 
This study is just applicable for teaching reading comprehension. As a result, future studies can examine the efficiency of CALL wise programs or lesson plans of other skills. The novelty of CALL provides more studies and more researches.

\section{Refrences}

Arishi, S. A. (2012). Attitudes of Students at Saudi Arabia industrial colleges toward computer-assisted Language learning (CALL). Teaching English with Technology, 12(1), 38-52.

Beatty, K. (2003). Teaching and Researching Computer Assisted Language Learning. New York: Longman.

Chapelle, C. A. (2003). English Language Learning and Technology. Amsterdam/Philadelphia: John Benjamins Publishing Company.

Chastain, K. (1988). Developing second-language skills: Theory and practice, (3th). San Diego, CA: Harcourt Brace Jovanovich, Inc.

Chen, J. (1996). CALL is not a hammer and is not every teaching problem is a nail: Changing expectations of computers in the classroom. the Internet TESL Journal , 3(1), 1-4.

Cooper, P.A. (1993). Paradigm shifts in designed instruction: From behaviorism to cognitivism to constructivism. Educational Technology 33: 12-19.

Lai, C., \& Kritsonis, W. A. (2006). The advantages and disadvantages of computer technology in second language acquisition. National journal for publishing and mentoring doctorial student research , 3 (1).pp.11-13.

Dudeney, G., \& Hockly, N. (2008). How to teach with technology. England: Longman.

Duke, N. K., \& Pearson, D. P. (2002). Effective practices for developing reading comprehension. International Reading Association , 3, 205-242.

Egbert, J. (2005). CALL Essentials: Principles and practices in CALL. Virginia: TESOL.

Fallon, C., \& Brown, S. (2003). E-learning Standards. United States of America: CRC Press LLC.

Fardy, M., Namdar, L., Farhadi, S., Noori Shoorabi, H., \& Saboori, A. (2011). the effect of using computer- assisted language learning(CALL) on the reading comprehension of expository texts for the Iranian university female seniors. Journal of Academic and Applied studies , 1(2), 1-7.

Gips, A., Diamattia, P., \& Gips, J. (2004). The effect of assistive technology on educational costs: two case studies. Published in Computers Helping People with Special Needs. K. Miesenberger, J. Klaus, W. Zagler, D. Burger (eds.). Springer-Verlag, 2004. 206-213.

Lee, K. (2000). English Teachers' Barriers to the use of computer-assisted Language Learning. the International TES Journal . Hsuan Chuang University ,Hsinchu, Taiwan.

Levy, M. (1997). Computer-Assisted Language Learning Context and conceptualization. Oxford, Uk: Clarendon Press. Moras, Solange. Computer-Assisted Lanaguage Learning (Call) And The Internet. Karen's Linguistic Issues, 2001.

Morrison, d. (2003). E-learning Strategies. England: John Wiley \& Sons Ltd.

Nunan, D. (2006). Second Language Teaching and Learning. Harlow, Portland: Heinle and Heinle.

Onsoy, S. (2004). students' and teachers' attitudes toward the use of Computer-Assisted Language Learning at the preparatory school of Celal Bayar University, a master thesis.

Richards, J. C., \& Schmidt, R. (2002). Longman Dictionary of Language Teachimg and Applied Linguistics. London: Longman.

Seljan, S., Berger, N., \& Dovedan, Z. (2002). Computer-Assisted Language Learning (CALL).

Warschauer, M., \& Healey, D. (1998). Computer and language learning: an overview. Language Teaching Journal 31, printed in United Kingdom, Cambridge University Press. PP. 57-71. 